\title{
How Much Do They Know? An Examination of Student Perceptions of University Cutbacks
}

\author{
Beth A. Postlewaite \\ Malone University \\ Julia A. Frankland \\ Malone University
}

Before the reality of COVID 19 surfaced, many universities faced economic uncertainties due to decreased revenues. Small, private, nonprofit universities are tuition-dependent and must lower costs to remain financially viable. This study investigates how much students understand about the financial situation of their University and how the decrease in university spending impacted student experience. We surveyed a sample $(n=30)$ of recent graduates from the business department of a small, private, nonprofit university to gain a better understanding of how recent graduates perceived the financial decisions made by the administration and the outcomes of those decisions on their experiences. Questions asking about program cuts and other substantial decreases showed that these actions were widely recognized by students, even as the administration worked hard to limit their effects on the overall student experience. The findings indicate that most students are aware of the University's financial state, so leaders must develop communication strategies for current students and alumni built on trust and transparency as part of an overall strategy for long-term financial sustainability.

Keywords: higher education, university sustainability, tuition discounting, communication, student perception, price elasticity of demand

\section{INTRODUCTION}

Modern university leaders confront difficult decisions regarding the future of their institutions because of financial challenges. Fiscal pressures threaten university sustainability at many institutions, even those that had been financially successful for decades. Researchers have conducted prior research on university finances and the impact of decreased government spending in higher education. However, there is little understanding of how college students perceive the financial situation of the University.

\section{BACKGROUND OF THE PROBLEM}

\section{The Great Recession of 2007-2008}

The Great Recession negatively impacted the revenues of many U.S. universities and colleges. To balance state budgets, government officials in many states cut funding for higher education (Barr \& Turner, 2013; Long, 2014). Additionally, Dorantes and Low (2016) indicated that universities suffered losses in 
tuition revenues, gift income, and investment income from endowments because of the recession. Endowment losses decreased revenue, which caused university leaders to make budget cuts and rely more heavily on income from tuition (Barr \& Turner, 2013; Geiger, 2015). However, the loss of wealth and diminished income of families affected by the economic downturn increased the need for institutional aid or tuition discounts lowering net tuition (Barr \& Turner, 2013). Decreases in state funding, endowment losses, and fewer tuition dollars per student lower university revenue.

After the economic downturn, small, private, nonprofit colleges and universities realized financial shortfalls causing some to fail. Stowe and Komasara (2016) stated closed universities exhibited lower totals for assets, liabilities, revenues, and expenses than universities that remain open. Even though demand for education increased during the recession, operating funds decreased at many institutions because of lower university revenue (Barr \& Turner, 2013). One reason is that leaders of private, nonprofit colleges and universities confronted enrollment challenges by heavily discounting tuition to address the perception that private education is not an affordable option (Rine \& Guthrie, 2016). Some well-respected and longstanding private colleges and universities are undergoing financial hardships or have already closed their doors because of lower revenues, in part, due to higher discount rates (Rine \& Guthrie, 2016).

\section{Tuition Discounts}

Tuition discounting is both a solution for and a root cause of the financial shortfalls some institutions face. Leaders use the high price-high aid model to increase enrollment numbers, infer educational quality, attract superior students, and increase diversity (Rine, 2019). There are two types of tuition discounts. Unfunded discounts often come from a university's general fund, and funded discounts are institutional aid earmarked specifically for lowering tuition for some students (Behaunek \& Gansemer-Topf, 2019). Behaunek and Gansemer-Topf (2019) indicated that university leaders often divert the money from other areas within the University to offer unfunded discounts. Conversely, Rine (2019) stated many unfunded scholarships are merely discounts off the institutions' inflated, stated price.

Behaunek and Gansemer-Topf (2019) identified decreased demand, high tuition prices, and unfunded discounts as factors that cause tuition-dependent institutions to suffer or fail. Similarly, Caskey (2018) determined that tuition discounts may decrease revenues and lower academic and extracurricular programming quality. Additionally, if the discounts do not attract enough new students to cover the marginal cost per student, leaders of private universities may have to abandon the widely used practice of discounting tuition by offering merit-based and need-based scholarships they currently use to be competitive in the market (Caskey, 2018).

\section{Competition in Higher Education}

Competition from public, for-profit, and other nonprofit institutions may threaten the sustainability of nonprofit colleges and universities. Deegan and Deegan (2014) indicated many nonprofit institutions struggle because of a combination of continuous undercapitalization and increased competition in the market. Panda, Pandey, Bennett, and Tian (2019) found that the increase in competition results from reductions in barriers to enter the market and a lack of differentiation between colleges and universities. Therefore, some institutions will face extinction because of financial shortfalls as students gain more choice of educational providers. However, although competition for students is increasing, the changing demographics indicate that the demand for education in some areas is shrinking (Marcy, 2017).

Demographic changes in the United States produce new challenges for leaders of small, private, nonprofit universities. Grawe (2018) relayed that the Midwest and Northeast, home to many institutions of higher education, will undergo a 15\% or greater drop in high school graduation rates. Eide (2018) and Marcy (2017) also predicted there will be a persistent decline in the college-age population over the next several years, and regions with the highest concentration of private colleges and universities will experience the largest drop in population. Decreased demand for higher education in areas heavily saturated with private colleges and universities creates intense competition and lower tuition revenues that will put additional strain on underfunded universities (Marcy, 2017). Increased competition and decreased demand 
for education caused by changes in demographics threaten the sustainability of nonprofit colleges and universities. University leaders should consider various adaptive strategies for university sustainability.

\section{Adaptive Strategies}

Adaptive strategies vary according to the type of University or college (Brint et al., 2016). Rine and Guthrie (2016) examined four indicators of successful universities consisting of access, affordability, student outcomes, and financial sustainability from 118 institutional members of the Council for Christian Colleges and Universities (CCCU) to offer guidance to evangelical leaders regarding using empirical data for sustainability. The authors found university leaders of Christian institutions should create systems to collect and use data for benchmarking, measuring performance longitudinally, and communicating findings to stakeholders (Rine \& Guthrie, 2016). However, Breneman (2012) questioned the usefulness of gathering and disseminating data during times of rapid change because, by the time researchers analyze the data, it may no longer be relevant. Therefore, leaders should consider incorporating historical findings, but they should consider altering the designed course.

Leaders might establish flexibility in institutional processes for universities and colleges to survive. Barnard and Van der Merwe (2016) contended leaders should focus on developing agile organizations that create and utilize knowledge. Other scholars have performed studies to test this claim. For example, Brint et al. (2016) found that university leaders who successfully managed their institutions during challenging times were adaptable and armed with adequate resources for survival. In another study, Tarrant, Bray, and Katsinas (2018) discovered many private, nonprofit, nonselective colleges and universities persisted over several decades because their leaders created adaptive strategies to overcome obstacles. Moran (2016) studied the organizational resilience of smaller, nonprofit universities and colleges confronting decline and found the most effective response factors are goal-directed seeking and avoidance. Conversely, Brint et al. (2016) found that leaders who successfully navigated through difficult times used a combination of approaches for success. The approaches included a focus on customer service, market search, and environmentally friendly growth (Brint et al., 2016). Leaders can learn more about these approaches by gathering data regarding student perception of the process and results of the University's decisions.

\section{Consumer Mentality}

Over the past two decades, researchers have noted a trend in students perceiving themselves as the consumers and higher education as the good they are consuming. Millican (2014) examined data collected from first and second-year college students who participated in surveys, interviews, and focus groups and found that, over time, students have begun to view themselves as consumers. Other scholars have discussed the resulting shift from learner to customer due to the marketization of higher education (Feigenbaum \& Iqani, 2015; Purcell, 2014; Staddon \& Standish, 2012; White, 2007). Millican cautioned that educators need to temper the consumerist view of higher education because the research shows it is not good for pedagogy or the University. Staddon and Standish (2012) indicated that faculty and staff's focus should be on improving the student experience through sound pedagogy.

Higher education has evolved over the centuries since its commencement into an industry driven by customer service (Allen \& Withey, 2017). Temple, Callender, Grove, and Kersh (2016) found that, in some instances, it is appropriate to treat students as customers. These occurrences relate to nonacademic areas of campus (Temple et al., 2016). However, because it can be difficult to create discrete academic and nonacademic programs, leaders sometimes incidentally make changes related to the student as a customer on the academic side (Temple et al., 2016). However, when the student is the customer, education becomes transactional (Allen \& Withey, 2017). Because university leaders are focused on the student experience and increasing brand loyalty, most leaders implement a student satisfaction measurement tool (Allen \& Withey, 2017). To better understand the student perspective, academic leaders should consider including questions regarding student perceptions in this instrument. 


\section{METHOD}

The motivation for this study originated in conversations with students during academic advising appointments. They had heard various pieces of information about the University's financial situation, but it was apparent early on that the understanding was limited at best. We chose a qualitative research method because we aimed to learn from the recent graduates about their experiences and perspective.

\section{Data Collection and Participants}

We desired to investigate the knowledge that recent graduates had of the financial situation of a small, private, midwestern university. Our target population included graduates who completed their bachelor's degrees in 2019 \& 2020 who graduated with majors from the Department of Business (Accounting, Business Administration, Finance, Marketing, Sport Management).

After receiving approval from the University's Institutional Review Board (IRB), we designed a survey with the University's Development Office and the Alumni Office. A colleague from the Development Office sent the Google Forms survey to 78 students at their current email addresses. The survey contained language notifying the respondents that their replies were anonymous and that we would not compensate them in any way for responding. The initial email request from the Development Office generated 16 responses to the survey. Individual follow-up emails from the authors to all graduates in the population generated 14 additional responses, giving us a $38.46 \%$ response rate (30 of 78 ). There is academic support for the use of follow-up emails to increase response rates. For example, Van Mol (2017) studied the use of reminders on response rates and found all types of reminders increased college students' response rates, a population suffering from survey fatigue, to acceptable levels. All responses submitted for this study were usable.

The survey consisted of 19 questions, the majority of which covered University financial information, with the remainder being department-specific information (i.e., The Department of Business prepared me for the job market). We included 14 questions using a Likert-style rating ranging in values from 1(strongly disagree) to 5 (strongly agree). Questions were formatted in a Likert-style rating because it is appropriate for the opinion data we aimed to collect (Saunders, Lewis, \& Thornhill, 2015). The remaining five questions were open-ended.

\section{RESULTS}

\section{An Examination of Recent Graduates' Understanding of University Finances}

Long run survival of universities depends on the bottom line. An organization is financially sustainable when leaders meet their current and future financial needs with transparency and trustworthiness while actively pursuing their mission (Gajdová \& Majdúchová, 2018). However, changes in the external environment threaten university sustainability.

The higher education sector confronts the ongoing challenge of generating enough revenue to cover operation costs, particularly in the Midwest, where the pool of available local applicants is shrinking due to demographics. The discussion regarding the shifting of demographics is not a novel concept. In 2018, Grawe stated a decline in the potential demand for higher education threatened regional institutions' sustainability in the Midwest. Universities can borrow money, if needed, to cover an unexpected shortfall, though banks and accrediting bodies are not enthusiastic when these actions occur frequently. These actions are occurring more often. Overall, institutional borrowing for mid-level, nonprofit universities is increasing. Between 2003 and 2012, nonprofit and public colleges saw an increase in interest payments from institutional debt increase from 6 billion to 11 billion dollars (Eaton et al., 2016).

It seems reasonable to expect that recent graduates with degrees in business and related fields could understand the financial situation of their University. Most graduates should be competent in applying their understanding of the market function and the related aspects of a successful enterprise, but few surveyed completed that task well. 
Only $36.7 \%$ of recent graduates agreed or strongly agreed that they understood the financial position of the University, while $30 \%$ disagreed or strongly disagreed. (See Figure 1) The recent graduates participating in this study represented a sample of those who persisted to earn their degrees, so ultimately their business-related curriculum is complete. While their exposure to financial principles would permit understanding, likely this topic is not something of concern as they are starting their careers.

\title{
FIGURE 1 \\ UNDERSTANDING OF UNIVERSITY FINANCIAL POSITION
}

Indicate your level of agreement with this statement: I understand the financial position of the University

30 responses

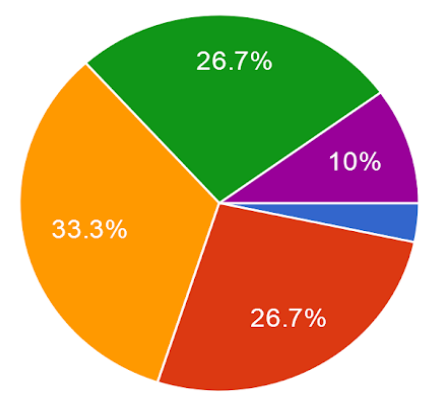

\author{
Strongly disagree \\ Disagree \\ Neutral \\ Agree \\ Strongly agree
}

We asked recent graduates to select the primary source of funding for the University from a list of possibilities (tuition, endowment, donations/fundraising). Only $70 \%$ of all recent graduates correctly identified tuition as the main source of revenue, with only $36.7 \%$ of respondents agreeing or strongly agreeing that they understood the financial situation of the University (see Figure 2). The findings were somewhat surprising, as some recent graduates struggled to recognize the primary source of revenues for the University, and most lacked confidence in their understanding.

FIGURE 2

UNDERSTANDING OF FUNDING SOURCES
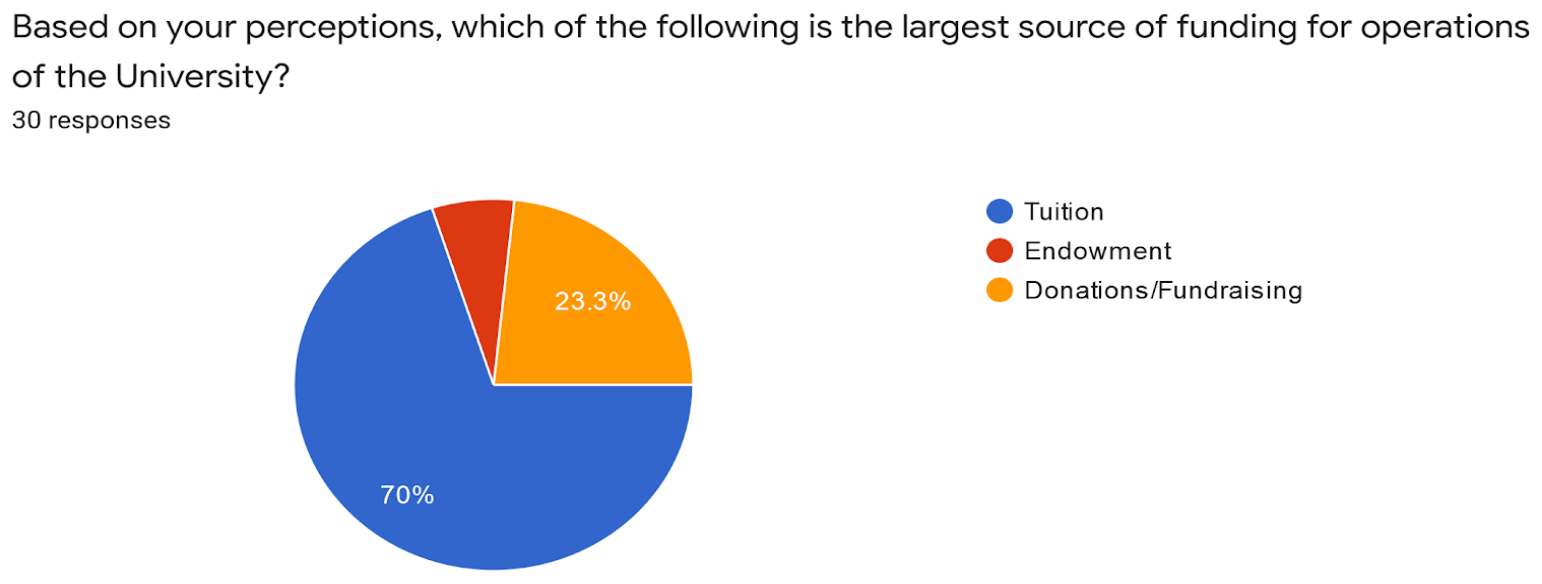

For those indicating confidence in understanding university finances, that confidence was somewhat misplaced, as $27 \%$ of respondents incorrectly identified the main source of revenue. Of that subset of respondents, $6.7 \%$ answered that the endowment was the main source of revenue. As a university with just 
over twenty-one million dollars in endowment, survival would be short-lived if that were accurate. The remaining $23.3 \%$ selected donations/fundraising as the main source of funding.

There are several possible explanations for the views of the students. Noticeable program and faculty reductions contribute to an overall sense of fiscal difficulties, but the lack of a clear information path may have inhibited their knowledge. This assumption is consistent with results from a student survey performed by the Higher Education Policy Institute in the United Kingdom (Buckley, Soilemetzidis, \& Hillman, 2015). Results from over 15,000 surveys indicated only $18 \%$ of students felt university leaders communicated how they were spending their tuition dollars, and $75 \%$ of respondents indicated that the universities did not provide them with enough information about the monies (Buckley et al., 2015). It is also conceivable that it never occurred to the students to question the financial solvency of their college.

\section{An Examination of Recent Graduates' Understanding of the Discount Rate}

With tuition serving as the primary revenue stream for the University's operations, we asked graduates about their understanding of education's price. At the University of study, the 2019-2020 academic year's tuition was just under $\$ 31,000$, though few paid full price. Over $90 \%$ of students received some form of financial aid. Using the discount rate to attract and retain students at private universities is a commonly used strategy. Rine and Guthrie (2016) found that leaders use discounting as an enrollment strategy to address the perception that private education is not an affordable option.

The actual tuition paid by undergraduate students varies greatly due to tuition discounting. Tuition discounting is the process of lowering stated tuition prices with institutional grants such as merit-based, need-based, or characteristic-based scholarships used by university administrators to attract new students (Rine, 2019). The average discount rate for athletes was $73 \%$ in $2019-2020$, and $63 \%$ for nonathletes. The larger the discount rate, the lower the amount of tuition paid by the student.

It is essential to gauge the students' understanding of concepts such as tuition revenue and discount rates. For students at private, nonprofit universities, the relevant tuition is the net price they pay, not the education's sticker price (Barr \& Turner, 2013). Therefore, a lower discount rate could lead to lower enrollment numbers which would negatively impact the financial situation of some private, nonprofit institutions. Too high of a discount rate can negatively affect tuition revenue because the University will collect fewer tuition dollars per student (Rine, 2019). Fewer tuition dollars may lead to visible declines in quality, such as deferred maintenance, deteriorating buildings, and an inability to keep pace with the competition in offering new and improved facilities on campus. Stakeholders are sensitive to quality issues, and institutions that provide a quality education will attract better students (Eftimov, Trpeski, Gockov, \& Vasileva, 2016).

Because of how admissions counselors offer financial aid packages, universities can practice price discrimination, the act of separating students based on their willingness to pay (student demand), and the price elasticity of demand for the product of education. As government aid for students has decreased, the direct cost of education to students has increased. The direct costs and the opportunity costs (due to lost work income) of education have become too high for some financially disadvantaged, potential students to enroll in college (Fincher \& Katsinas, 2017). To entice students to overcome the opportunity costs, universities must offer aid packages to lower education's direct cost. Aid packages are a mix of loans, grants, and tuition discounts based on the individual's characteristics. Most students may recognize changes in the price of their tuition from year to year, but they are less able to recognize the concept of tuition discounting. We included two survey questions related to tuition discounting. We first asked: In your own words, explain the concept of the discount rate as it pertains to university funding. Of the 30 responses, only eight attempted a guess, with five being broadly correct. Two respondents' attempts did not address the question, and one correctly identified the "other" Discount Rate, the monetary policy tool used by the Federal Reserve System. The responses are in Table 1 below. 


\section{TABLE 1 \\ RECENT GRADUATES' RESPONSES RELATED TO THE DISCOUNT RATE}

\begin{tabular}{l} 
A type of funding that awards students with academic or even athletic scholarships, grants, etc. In order to \\
ensure that the students are not paying the full price of tuition (sticker price). \\
\hline Discount rate is the average percentage off tuition \\
Discounts maybe coming in form f tuitions and grants? NA? Not sure if discounts and scholarships or grants \\
means the same thin. \\
From what I have experienced at the two private institutions I attended the discount rate is massive. Most kids \\
received a quarter of tuition off even if their parents made a significant income. This only increased for those in \\
more compromising circumstances. I do not understand why schools list their price of tuition so high when \\
most of the student body gets a discounted rate. As it pertains to university funding the only think I could \\
assume is that the small percent that actually pay the full price adds up to a significant enough amount for \\
added funds. \\
Scholarships or discounts given to first year students. \\
The discount rate continues to increase to incentives students to come to Malone, however if the discount rate \\
keeps increasing the amount of funding coming back to Malone decrease therefor Malone will not be able to \\
sustain itself longterm \\
Unsure what this is referring to ... scholarships? \\
The rate at which member banks are able to borrow from the fed. Sets a baseline for interest rates in the \\
market.
\end{tabular}

As a follow-up question, we asked students: Did the average discount rate increase or decrease over the years you were at the University? Responses varied widely across the 30 survey respondents. In the subset of students who had correctly identified the discount rate concept, there was roughly equal distribution between those who said the discount rate increased and those who said it decreased. Recall that Behaunek and Gansemer-Topf (2019) cautioned leaders of tuition-dependent institutions not to overuse unfunded tuition discounts because they are simply moving money from a general operating fund to use as institutional aid. This transfer of funds could reduce the ability to balance the budget even with the increase in students that the use of unfunded tuition discounts attracts. Therefore, it is important to know what the students understand about tuition discounting and the impact on their actual price of education. For our sample of recent graduates, a possible explanation is that the respondents did not identify the term 'discount rate' per se. Given the few identification attempts of the term discount rate, a rewording of the question to include more familiar terminology (the price of your education, for example) may have yielded greater recognition of changes in discounting.

Pricing appears to be important to the survey respondents. Over $73 \%$ of respondents agreed or strongly agreed that they were searching for a good value when shopping for a university. (See Figure 3) Price often serves as an indicator of quality. Rao and Monroe (1989) found positive and significant relationships between price and perceived quality for consumer goods. Lawson and Zerkle (2006) found evidence to support the theory that universities practice price discrimination. The authors studied a private university in the Midwest and found poorer and better students paid less than average, wealthier students (Lawson \& Zerkle, 2006). This finding is consistent with the economic theory that better students are more price elastic because they have more choice in education. In addition, poorer students are more price elastic because tuition is a larger portion of their family's income. However, this pricing model may no longer apply to higher education. Fincher and Katsinas (2017) found that raising the price of higher education in the current environment will likely be accompanied by a decrease in enrollment because funding models are now high price low aid rather than high price high aid. So, as long as the institution is still using the high price, high aid model, they may continue to attract students with large discounts. Recall that if the discounts do not attract enough new students to cover the marginal cost per student, leaders may have to walk away from the practice that allows them to compete in the market (Caskey, 2018).

Students comparing the price listed on the websites to their final discounted price on their tuition bills may experience greater perceived consumer surplus for the product (education) they are purchasing. 
Completing the application process required by the University suggests at least a willingness to consider the full purchase price listed. Financial aid packaging with discounted tuition and other awards increases the difference between the price paid and what the consumer is willing to pay. The $73 \%$ response rate suggests that students love a 'sale.' While they are not certain about the overall differences in advertised tuition and discounted tuition for the average student, they are aware of their personal pricing model and seek to maximize their consumer surplus.

\section{FIGURE 3 \\ RELATIONSHIP BETWEEN RECENT GRADUATES' UNIVERSITY CHOICE AND ECONOMIC VALUE}

Indicate your agreement with this statement: I was looking for a 'good value' when I chose Malone

University.

30 responses
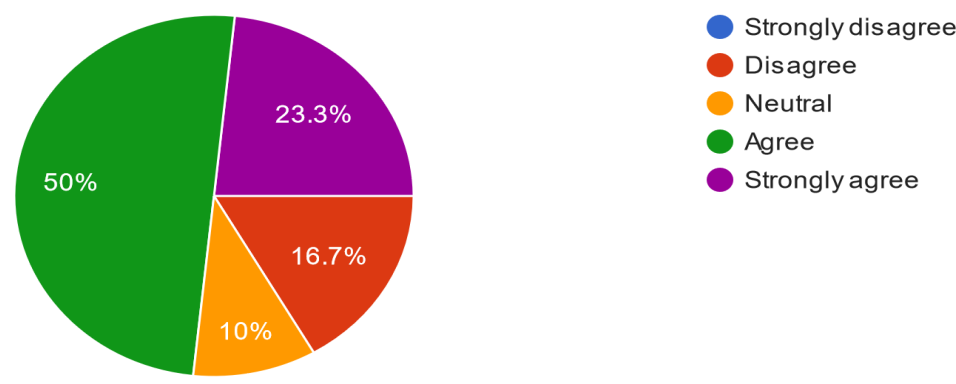

An Examination of Recent Graduates' Awareness of Budget Cuts

Caskey (2018) warned of declines in the quality of academic and extracurricular activities when tuition discounts fail to attract students and revenues fall. Even though the graduates surveyed did not have clear understandings of discount rates, they did recognize changes in the programs and activities offered. Twenty-six graduates $(86.7 \%)$ believed there to be programs or majors cut in the last five years (see Figure 4). Budget cuts are one way that university leaders can contend with fiscal constraints, however, leaders must be careful not to make too many cuts in crucial areas of the University (Deering \& Sa, 2014).

\section{FIGURE 4}

\section{RECENT GRADUATES' AWARENESS OF BUDGET CUTS}

To the best of your knowledge, were any programs or majors cut from the University's curriculum in the last five years?

30 responses

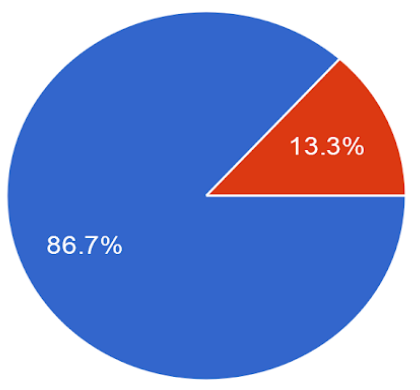


Leaders should consider the impact on the student experience and students' perception of reductions before eliminating programs, staff, or faculty. Buckley et al.'s (2015) analysis of 15,000 student surveys from the United Kingdom revealed that most students understood that budget cuts should not impact the faculty and staff who are integral to offering high-quality education, but institutions should spend less on buildings, sports, and social organizations.

We asked graduates if they were aware of budget cuts in the last year that would impact the student experience and if yes, how? We received mixed results, and responses primarily reflected how the cuts affected them as individuals instead of the University as a whole. During the spring of 2019, the University eliminated its NCAA Division II football program for budgetary reasons with little notice to the team members. This elimination understandably shook up the student body, leaving them angry and concerned. Six respondents specifically mentioned the football program cuts, with an additional four students recognizing cuts to athletics in general. The students also identified cuts to faculty, with several specifically recognizing the elimination of a well-loved Executive in Residence. The questions around this topic indicate growing evidence of student awareness at the micro level (How does this change impact me?) but less so at the macro level (How does this change impact others or the community as a whole?). For example, when asked about budget cuts, one student responded, "I have been aware of budget cuts but would argue that I personally was not impacted. I would think that it would impact other students' experience but speaking for myself, I did not feel impacted." Although the University experienced some rather substantial changes in programming, staffing, and athletics, eight graduates responded that they were not aware of budget cuts that would impact the student experience.

\section{An Examination of Recent Graduates' Retention Behavior}

As with the operation of most competitive businesses, a university can only survive in the long run through the ongoing demand for the products by customers. Universities must be able to attract new students and retain existing students to cover costs. To gauge the impact of financial concerns on retention, we asked if these recent graduates had ever considered transferring because of concern about the University's longterm financial viability. We were expecting a response that would show that some students had considered transferring, but the results were concerning. Twelve recent graduates, $40 \%$, of the respondents who studied business and related majors had considered transferring because of the University's financial concerns (see Figure 5). The number may be exaggerated because of two large shocks that impacted them personally, eliminating the football program and not renewing the contract of an Executive in Residence for budgetary reasons. Although few of the graduates competed in the football program, many had friends and classmates who did participate. As those students sought alternative schools to play football, the remaining students experienced the sudden loss of friends, which may have triggered an investigation into changing schools. While $40 \%$ admitted that they considered transferring (see Figure 5), all of these individuals stayed and finished their degrees. One possible explanation is that the opportunity cost of changing schools was too high. These students were nearing completion of their programs of study and potentially had job opportunities or family nearby. 


\title{
FIGURE 5 \\ RECENT GRADUATES' RESPONSES TO QUESTION REGARDING TRANSFERRING
}

\author{
Did you ever consider transferring to another college because you were concerned about the \\ University's long term financial viability? \\ 30 responses
}

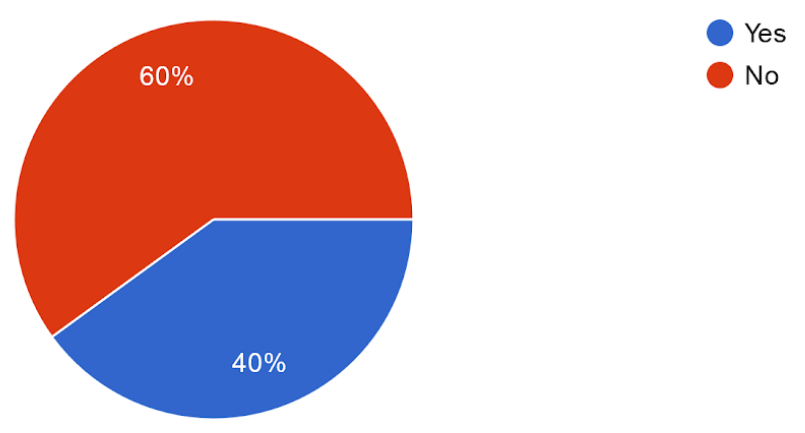

\section{DISCUSSION}

The importance of communicating with students regarding their education's perceived value is more significant than ever because higher education has become more competitive, demographics have shifted, and government spending on higher education has decreased. University leaders should learn about how to differentiate their institutions in the eyes of the student consumer. Our findings indicate students' understanding of University financing is deficient. This lack of awareness offers an opportunity for university leaders to communicate better with potential and current students. University leaders' ability to use high discount rates to attract students seems to indicate college students are becoming more price elastic when it comes to their education. However, small, private, nonprofit institutions are limited in their revenue streams and rely on tuition revenue and a return on their endowment investments (Rine \& Guthrie, 2016). If the endowment returns are insufficient, then these universities become even more reliant on tuition revenue. Some university leaders will need to gain more revenue from tuition, thereby decreasing institutional student aid, to make up for endowment losses (Geiger, 2015). However, by practicing price discrimination, university leaders may be able to decrease the overall discount rate by only offering higher discounts to the students who are highly responsive to a change in price.

To overcome the challenges related to a lower discount rate, leaders should consider using non-price differentiation in their communications with students. Reliance on discounting alone can instigate a price war with other regional universities. Rine (2019) asserted that tuition discounts could elicit strategic reactions from the University's competitors, causing discounts to spiral out of control. Our findings indicate students do not fully understand the concept of tuition discounting or its impact on the price they pay for the education or the quality of education. Perhaps, by better understanding students' perceptions and understanding of university finances and their impact on the student experience, leaders can strengthen their communications to students and improve enrollment numbers without increasing the discount rate.

Leaders might consider focusing their communications on how tuition dollars directly affect the students' quality of education. Survey responses indicated graduates had an individualistic perspective; therefore, leaders should consider personalized communication about how leaders conscientiously use their tuition dollars when engaging with potential and current students. This approach is consistent with Schwieger and Ladwig's (2018) literature review in which they recognized that Gen Zer's are budgetoriented, look for personalized experiences, and that storytelling influences their choices. University leaders should consider how they communicate with future and current students to remain viable in the long run. 


\section{REFERENCES}

Allen, P., \& Withey, P. (2017). The student customer phenomenon. Journal of Higher Education Theory and Practice, 17(3), 45-56. Retrieved from https://www.articlegateway.com/index.php/JHETP/article/view/1552

Barnard, Z., \& Van der Merwe, D. (2016). Innovative management for organizational sustainability in higher education. International Journal of Sustainability in Higher Education, 17, 208-227. doi:10.1108/IJSHE-08-2014-0120

Barr, A., \& Turner, S.E. (2013). Expanding enrollments and contracting state budgets: The effect of the Great Recession on higher education. ANNALS of the American Academy of Political and Social Science, 650, 168-193. doi:10.1177/0002716213500035

Behaunek, L., \& Gansemer-Topf, A. (2019). Tuition discounting a small, private, baccalaureate institutions: Reaching a point of no return? Journal of Student Financial Aid, 48(3), 1-25. Retrieved from https://www.nasfaa.org/Journal_of_Student_Financial_Aid

Breneman, D.W. (2012). Perspectives: Education policy research in uncertain times. Change: The Magazine of Higher Learning, 44(6), 33-36. doi:10.1080/00091383.2012.728952

Brint, S., Yoshikawa, S.R.K., Rotondi, M.B., Viggiano, T., \& Maldonado, J. (2016). Surviving and thriving: The adaptive responses of U.S. four-year colleges and universities during the Great Recession. The Journal of Higher Education, 87, 859-885. doi:10.1353/jhe.2016.0032

Buckley, A., Soilemetzidis, I., \& Hillman, N. (2015). HEPI-HEA Student Academic Experience SurveyHEPI. Retrieved from https://www.hepi.ac.uk/2015/06/04/2015-academic-experience-survey/

Caskey, J.P. (2018). Tuition discounting in liberal arts colleges. Change: The Magazine of Higher Learning, 50(6), 52-58. doi:10.1080/0091383.2018.1540830

Deegan, M.B., \& Deegan, J. (2014). Unfunded tuition discount rate and net operating revenue: A balancing act. College \& University, 89(3), 55-59. Retrieved from https://www.muse.jhu.edu/journal/172

Deering, D., \& Sá, C.M. (2014). Financial management of Canadian universities: Adaptive strategies to fiscal constraints. Tertiary Education \& Management, 20, 207-224. doi:10.1080/13583883.2014.919604

Dorantes, A.R., \& Low, J.R. (2016). Financial crisis management in higher education: Responses by 20 private colleges and universities to the 2007-2009 financial crisis. Journal of Education Finance, 42, 188-219. Retrieved from https://www.muse.jhu.edu/journal/442

Eaton, C., Habinek, J., Goldstein, A., Dioun, C., Godoy, D.G.S., \& Osley-Thomas, R. (2016). The financialization of U.S. higher education. Socio-Economic Review, 14, 507-535. doi:10.1093/ser/mwv030

Eftimov, L., Trpeski, P., Gockov, G., \& Vasileva, V. (2016). Designing a balanced scorecard as strategic management system for higher education institutions: A case study in Macedonia. Ekonomika, 62(2), 29-48. doi:10.5937/ekonomika1602029E

Eide, S. (2018). Private colleges in peril: Financial pressures and declining enrollment may lead to more closures. Education Next, 18(4), 34-41. Retrieved from https://www.educationnext.org

Feigenbaum, A., \& Iqani, M (2015). Quality after the cuts? Higher education practitioners' accounts of systemic challenges to teaching quality in times of 'austerity'. Journal of Further and Higher Education, 39(1), 46-66, doi:10.1080/0309877X.2013.778961

Fincher, M., \& Katsinas, S. (2017). Testing the limits of the price elasticity of potential students at colleges and universities: Has the increased direct cost to the student begun to drive down higher education enrolment? Journal of Higher Education Policy and Management, 39(1), 31-39. https://doi.org/10.1080/1360080X.2016.1211975

Gajdová, D., \& Majdúchová, H. (2018). Financial sustainability criteria and their testing in the conditions of the Slovak nonprofit sector. Contemporary Economics, 12, 33-56. doi:10.5709/ce.18979254.262 
Geiger, R. (2015). Impact of the financial crisis on higher education in the United States. International Higher Education, 59, 9-11. Retrieved from www.ejournals.bc.edu/index.php/ihe

Grawe, N. (2018). Advancing the liberal arts in the face of demographic change. Liberal Education, 4, 611. Retrieved from https://www.aacu.org/publications-research/periodicals/Liberal\%20Education

Lawson, R.A., \& Zerkle, J.H. (2006). Price Discrimination. Journal of Economics and Finance Education, 5(1), 1-7. Retrieved from https://www.economicsfinance.org/jefe/econ/Lawsonpaper.pdf

Long, B.T. (2014). The financial crisis and college enrollment: How have students and their families responded? In J.R. Brown \& C.M. Hoxby (Eds.), How the financial crisis and Great Recession affected higher education (pp. 209-233). doi:10.7208/chicago/9780226201979.001.0001

Marcy, M.B. (2017). Beyond mere survival: Transforming independent colleges and universities. Change: The Magazine of Higher Learning, 49(3), 36-44. doi:10.1080/00091383.2017.1321435

Millican, J. (2014). Higher education and student engagement: Implications for a new economic era. Education + Training, 56(7), 635-649. doi:10.1108/ET-07-2014-0077

Moran, K.A. (2016). Organizational resilience: Sustained institutional effectiveness among smaller, private, nonprofit U.S. higher education institutions experiencing organizational decline. Work, 54, 267-281. doi:10.3233/WOR-162299

Panda, S., Pandey, S.C., Bennett, A., \& Tian, X. (2019). University brand image as competitive advantage: A two-county study. International Journal of Educational Management, 33, 234-251. doi:10.1108/IJEM-12-2017-0374

Purcell, W. (2014). Disruption and distinctiveness in higher education. Perspectives: Policy and Practice in Higher Education, 18(1), 3-8. doi:10.1080/13603108.2014.882426

Rao, A.R., \& Monroe, K.B. (1989). The effect of price, brand name, and store name on buyers' perceptions of product quality: An integrative review. Journal of Marketing Research, 26(3), 351-357. doi:10.1177/002224378902600309

Rine, P.J. (2019). The discounting dilemma: Institutional benefits, unintended consequences, and principles for reform. Christian Higher Education, 18, 16-23. doi:10.1080/15363759.2018.1543242

Rine, P.J., \& Guthrie, D.S. (2016). Steering the ship through uncertain waters: Empirical analysis and the future of evangelical higher education. Christian Higher Education, 15, 4-23. Retrieved from https://www.tandf.co.uk/journals

Saunders, M.N.K., Lewis, P., \& Thornhill, A. (2015). Research methods for business students (7th ed.). Essex, England: Pearson Education Limited.

Schwieger, D., \& Ladwig, C. (2018). Reaching and retaining the next generation: Adapting to the expectations of Gen Z in the classroom. Information Systems Education Journal, 16(3), 45-54.

Staddon, E., \& Standish, P. (2012). Improving the Student Experience. Journal of Philosophy of Education, 46, 631-648. https://onlinelibrary.wiley.com/doi/abs/10.1111/j.14679752.2012.00885.x

Stowe, K., \& Komasara, D. (2016). An analysis of closed colleges and universities. Planning for Higher Education, 44(4), 79-90. Retrieved from https://www.scup.org/page/phe

Tarrant, M., Bray, N., \& Katsinas, S. (2018). The invisible colleges revisited: An empirical review. The Journal of Higher Education, 89, 341-367. doi:10.1080/00221546.2017.1390971

Temple, P.A., Callender, C., Grove, L., \& Kersh, N. (2016). Managing the student experience in English higher education: Differing responses to market pressures. London Review of Education, 14(1), 33-46. doi:10.18546/LRE.14.1.05

Van Mol, C. (2016). Improving web survey efficiency: The impact of an extra reminder and reminder content on web survey response. International Journal of Social Research Methodology, 20, 317 327. doi:10.1080/13645579.2016.1185255

White, N.R. (2007). The customer is always right?: Student discourse about higher education in Australia. Higher Education, 54(4), 593-604. doi:10.1007/s10734-006-9012-x 